\title{
Implementation of Mass Customization for competitive advantage in Indian industries: a structural equation model
}

Piu Jain ( $\nabla$ piujaink@gmail.com )

Delhi Technological University https://orcid.org/0000-0002-2765-2848

\section{Suresh Garg}

Delhi Technological University

Gayatri Kansal

School of Engineering and Technology, IGNOU.(Former)

\section{Research Article}

Keywords: Mass customization, competitive advantage, manufacturing, Structural equation modelling

Posted Date: September 22nd, 2021

DOl: https://doi.org/10.21203/rs.3.rs-773220/v1

License: (c) (i) This work is licensed under a Creative Commons Attribution 4.0 International License.

Read Full License 


\section{Abstract}

The enduring fluctuations in market demand, exemplified by exceedingly unpredictable customer requirements have given rise to Mass customization, which is acquiring increasing prominence in production and operations management. Fostering on the foundation laid by erstwhile researcher Hart[1], who developed an analytical framework of four pillars of mass customization for organizations, the objectives of this research are to obtain additional discernments on the nature of linkage between the four pillars and $\mathrm{MC}$, in addition to their impact on competitive advantage. The current work is an attempt to explore the mass customization ability of manufacturing organizations of Indian origin and its impact on organisational performance and to propose a comprehensive assessment and decision-making model for manufacturers to implement mass customization for competitive benefits. Literature support is expanded and validated using data collected through survey conducted among managers of various divisions of organization of Indian origin. The final sample contains 276 usable observations. Data analysis was performed expending structural equation modelling(Amos Graphics).

\section{Introduction}

The outbreak of COVID-19 has augmented the challenges to globalization and the International Business arena eliciting economic turbulence, global value chain disruptions, stimuli of nationalism, and protectionism[2]. The aggrandizement of a post-COVID-19 business paradigm necessitates motivating challenges to ensure competitiveness and will require rethinking[3]. Given the scenario, $\mathrm{MC}$ necessitates embracing strategies and create a manufacturing model that promotes flexibility, provides quick customer response, price-competitive products, product design as per customers' needs, and attainment of business goals [4].

Several researchers have characterized mass customization as a production paradigm endowing profound strategic opportunities[5] with potentials of managerial response during a progressively uncertain, competitive, and intricate environment[6], having competitive positioning strategy in the marketplace[7] during the period exemplified by the introduction of innovative production technologies, increased global competitiveness, reduced product life cycles, and the customer need for more product diversity[8]. Organizations aiming to mass customize, on the other hand, will have hurdles in designing a system capable of acquiring and analyzing a wide range of complex and uncertain data [9]. The ability to manufacture mass customized goods is dependent on the ability of a corporation to use a range of production issues simultaneously, including quality, inventory, process technology, and human skills [5]. For effective application of their MC ability for competitive advantage, organizations must identify and exploit resources and skills effectively and efficiently[10]. This necessitates the development of a manufacturing model to identify the factors a manufacturer needs to consider for the effective implementation of $\mathrm{MC}$ in an organization.

Most of the research to enhance MC ability and to improve an organization's MC capabilities was carried out in the areas of organizational design and manufacturing practices or product and customer aspects 
like quality management [11], product modularity [12], functional integration [13], information technology [14], work-design practices[15], operations and marketing functions[16], supply chain integration[17], organizational learning and process technology[18], organizational structure [19], CAD/CAE integrated customization product approach[20], product modularity on supply chain quality integration[21]customer integration [22], degree of consumers involved in the value chain[23].Some studies identified technology needed like Industry 4.0 [24], RFID-enabled real-time manufacturing execution system[25], additive manufacturing [26], Computer-aided manufacturing planning[27]. None of these preceding research analyzed the role of operational agility required for $\mathrm{MC}$ ability. Organizations entailing to implement mass customization to enhance market competitiveness require to improve the operational agility of the $\mathrm{MC}$ production model to increase the flexibility, speed, and efficacy of responding to unique client needs [28].

Some research identified the role of enablers in manufacturing[29][30], but used ISM technology which is solely dependent on the judgment and qualitative inputs of few experts and was used to build theory, and testing of theory using structured questionnaire and in a single analysis, estimates of multiple and linked dependency were needed. Research work conducted was region-specific or product/ sector-specific, or both like Chinese automotive suppliers[31], door sector in Poland[32], pigment company in Taiwan[33], Shoe manufacturing in India[30]. Based on the above research study, the following gaps were observed:

- Manufacturing sectors in India identifying the possibility of moving away from mass manufacturing and toward mass customization requires a manufacturing model to enhance competitive advantage and tide over competitors and needed to identify operational agility to enhance MC ability.

This study aims to create a manufacturing paradigm that allows for mass customization and hence provides a competitive edge. The purpose is to employ analysis to experimentally resolve gaps in MC theory, with a focus on India's manufacturing industry and how customer, process, competition, and organizational factors affect mass customization capabilities for competitive advantage. The foundation laid by Hart (1995) on building an analytical framework and described as the four pillars of mass customization was further analyzed by using a structural equation modeling (SEM), which is used to analyze data from 276 manufacturing companies of Indian origin.

The paper is organized as follows: Sect. 2 represents theoretical background and hypothesis development. Section 3 highlights the research methodology. Section 4 presents Analysis and results. Section 5 articulates the Results and Discussion. The managerial implication of the study is provided in Sect. 6 . Section 7 conveys the limitation of the study and future research direction.

\section{Theoretical Background And Hypothesis}

The research is based on developing a manufacturing model for mass customization ability, as all operations in the product design, manufacturing, and delivery processes must be better coordinated and integrate[13]. To solve internal and external supply chain quality challenges, managers must use manufacturing and organizational design principles to improve mass customization capabilities [21]. Suppliers and customers amalgamation has a major impact on the agility and flexibility of an 
organization, which is necessary for MC capabilities[34]. Tookanlou and Wong [35] identified mass customization as a promising technique that has grabbed the interest of practitioners and researchers due to its potential to help firms gain a competitive advantage, generate profits and minimize waste through on-demand production. The hypotheses offered in this study are based on the four pillars of mass customization proposed by Hart (1995) and further strengthened by investigating the relationship between MC ability for competitive advantage from the extant literature. The constructs, related measurement items are presented in Table 1.

2.1 Customer sensitivity: The uniqueness of customers' demands and consumer sacrifice for unmet needs are the primary drivers of customer customization sensitivity [1]. To create mass customization capability, organizations must improve their operational efficiency, which necessitates the interchange of information between customers, salespeople, and technical personnel [36]. Customers must transform their wants and demands into particular product requirements [22] by customizing, setting, matching, or altering a solution, limiting the solution space to options already represented in the system's fulfillment, and converting consumer co-design data into customer knowledge for strategic planning and innovation [37][38]. Customer input to establish features and pricing requirements of personalized products to meet consumers' particular requirements cheaply and promptly [39], and a study of consumer buying patterns[40] can contribute to success in this field. Quick customer response for the implementation of mass customization is built on a system that connects consumer voice to product design, customer relationship management, regular market surveys, and understanding client grievances for product improvement [41]. Thus, the following hypotheses were advanced:

\section{Hypothesis $\mathrm{H} 1$}

Customer sensitivity is positively related to MC ability 
Table 1

Constructs, Measurement items with factor loads

\begin{tabular}{|c|c|c|c|c|c|}
\hline Constructs & Measurement Items & $\begin{array}{l}\text { Factor } \\
\text { Loads }\end{array}$ & $\begin{array}{l}\text { Cronbach's } \\
\text { Alpha ( } \\
0.70)\end{array}$ & $\begin{array}{l}\text { Item R- } \\
\text { Square }\end{array}$ & $\begin{array}{l}\text { CITC } \\
(> \\
0.30)\end{array}$ \\
\hline \multirow[t]{8}{*}{$\begin{array}{l}\text { Customer } \\
\text { Sensitivity }\end{array}$} & \multirow[t]{2}{*}{$\begin{array}{l}\text { CS1 Identify opportunities for } \\
\text { customization }\end{array}$} & 0.902 & \multirow[t]{8}{*}{0.958} & 0.814 & \multirow[t]{8}{*}{$\begin{array}{l}0.714- \\
0.874\end{array}$} \\
\hline & & 0.927 & & 0.859 & \\
\hline & $\begin{array}{l}\text { CS2 Understand the uniqueness of } \\
\text { customers' needs and create value }\end{array}$ & 0.845 & & 0.714 & \\
\hline & \multirow[t]{2}{*}{$\begin{array}{l}\text { CS3 Analyze customers sacrifice for } \\
\text { unmet needs }\end{array}$} & 0.883 & & 0.780 & \\
\hline & & 0.926 & & 0.857 & \\
\hline & $\begin{array}{l}\text { CS4 Provide ease of customer } \\
\text { choice for decision making }\end{array}$ & 0.865 & & 0.748 & \\
\hline & \multicolumn{2}{|l|}{ cS5 Create value for the customer } & & & \\
\hline & \multicolumn{2}{|l|}{$\begin{array}{l}\text { CS6 Incorporate customer } \\
\text { requirement during new design } \\
\text { process }\end{array}$} & & & \\
\hline \multirow{7}{*}{$\begin{array}{l}\text { Process } \\
\text { Amenability }\end{array}$} & \multirow{2}{*}{$\begin{array}{l}\text { PA1 Incorporate modularity in } \\
\text { design, for part flexibility }\end{array}$} & 0.825 & \multirow[t]{7}{*}{0.924} & 0.681 & \multirow{7}{*}{$\begin{array}{l}0.635- \\
0.784\end{array}$} \\
\hline & & 0.765 & & 0.585 & \\
\hline & $\begin{array}{l}\text { PA2 Develop compatible process } \\
\text { technology }\end{array}$ & 0.881 & & 0.776 & \\
\hline & \multirow{2}{*}{$\begin{array}{l}\text { PA3 Develop production and } \\
\text { distribution process for timely } \\
\text { delivery }\end{array}$} & 0.872 & & 0.760 & \\
\hline & & 0.863 & & 0.745 & \\
\hline & \multicolumn{2}{|l|}{ PA4 Develop supplier for co-design } & & & \\
\hline & \multicolumn{2}{|l|}{$\begin{array}{l}\text { PA5 Develop marketing competence } \\
\text { for product promotion }\end{array}$} & & & \\
\hline \multirow{5}{*}{$\begin{array}{l}\text { Competitive } \\
\text { Environment }\end{array}$} & CE1 Economic uncertainty & 0.771 & \multirow[t]{5}{*}{0.917} & 0.594 & \multirow{5}{*}{$\begin{array}{l}0562- \\
0.835\end{array}$} \\
\hline & CE2 Market Turbulence & 0.758 & & 0.575 & \\
\hline & \multirow{2}{*}{$\begin{array}{l}\text { CE3 Company credibility and } \\
\text { position in marketplace }\end{array}$} & 0.851 & & 0.724 & \\
\hline & & 0.868 & & 0.753 & \\
\hline & $\begin{array}{l}\text { CE5 Potential of competitors to } \\
\text { react }\end{array}$ & 0.873 & & 0.762 & \\
\hline
\end{tabular}




\begin{tabular}{|c|c|c|c|c|c|}
\hline Constructs & Measurement Items & $\begin{array}{l}\text { Factor } \\
\text { Loads }\end{array}$ & $\begin{array}{l}\text { Cronbach's } \\
\text { Alpha (> } \\
0.70)\end{array}$ & $\begin{array}{l}\text { Item R- } \\
\text { Square }\end{array}$ & $\begin{array}{l}\text { CITC } \\
(> \\
0.30)\end{array}$ \\
\hline \multirow{7}{*}{$\begin{array}{l}\text { Organizational } \\
\text { readiness }\end{array}$} & \multirow{2}{*}{$\begin{array}{l}\text { OR1 Cultural change in the } \\
\text { organization }\end{array}$} & 0.866 & \multirow[t]{7}{*}{0.954} & 0.750 & \multirow[t]{7}{*}{$\begin{array}{l}0.754- \\
0.867\end{array}$} \\
\hline & & 0.924 & & 0.854 & \\
\hline & $\begin{array}{l}\text { OR2 Skill development of } \\
\text { employees }\end{array}$ & 0.869 & & 0.755 & \\
\hline & \multirow{2}{*}{$\begin{array}{l}\text { OR3 Employee's involvement in } \\
\text { product and process roadmap }\end{array}$} & 0.914 & & 0.835 & \\
\hline & & \multirow{2}{*}{0.918} & & \multirow{2}{*}{0.843} & \\
\hline & $\begin{array}{l}\text { OR4 Training to marketing team to } \\
\text { capture and prioritize requirements }\end{array}$ & & & & \\
\hline & $\begin{array}{l}\text { OR5 Top management support and } \\
\text { leadership building }\end{array}$ & & & & \\
\hline \multirow{5}{*}{$\begin{array}{l}\text { Mass } \\
\text { Customization } \\
\text { Ability }\end{array}$} & \multirow{2}{*}{$\begin{array}{l}\text { MC1 Product can be customized on } \\
\text { large scale }\end{array}$} & 0.848 & \multirow[t]{5}{*}{0.908} & 0.719 & \multirow{5}{*}{$\begin{array}{l}0.647- \\
0.782\end{array}$} \\
\hline & & 0.833 & & 0.654 & \\
\hline & $\begin{array}{l}\text { MC2 Product variety can be } \\
\text { enhanced at same cost and quality }\end{array}$ & 0.862 & & 0.740 & \\
\hline & $\begin{array}{l}\text { MC3 Product can be designed } \\
\text { based on customers' requirements }\end{array}$ & 0.830 & & 0.689 & \\
\hline & $\begin{array}{l}\text { MC4 Product can be delivered on } \\
\text { stipulated time }\end{array}$ & & & & \\
\hline \multirow{6}{*}{$\begin{array}{l}\text { Competitive } \\
\text { advantage }\end{array}$} & \multirow{2}{*}{$\begin{array}{l}\text { CA1 Market share growth and } \\
\text { Reaching financial goals }\end{array}$} & 0.815 & \multirow[t]{6}{*}{0.906} & 0.664 & \multirow{6}{*}{$\begin{array}{l}0.584- \\
0.703\end{array}$} \\
\hline & & 0.812 & & 0.659 & \\
\hline & \multirow{2}{*}{$\begin{array}{l}\text { CA3 Increased sales volume/ Return } \\
\text { on sales/revenue }\end{array}$} & 0.846 & & 0.716 & \\
\hline & & 0.783 & & 0.613 & \\
\hline & CA4 Increased product variety & 0.813 & & 0.661 & \\
\hline & $\begin{array}{l}\text { CA5 Reduce waste through on } \\
\text { demand production }\end{array}$ & & & & \\
\hline
\end{tabular}

2.2 Process Amenability: Enablers, marketing and strategy, design, production, and distribution are all part of this diverse region[1]. New technology must be integrated and coordinated with humans and organizations to successfully execute mass customization [42]. Flexible manufacturing techniques are required by $M C$ to help businesses become first to market with unique, custom-made items. [43] to manage the complexity of mass customization [44]. Increasing product variety implies richer information flows, which in turn necessitates increased scheduling and coordination complications inside the organization [13][45], giving rise to increased information processing needs [13]. Organizations need to establish suitable information infrastructure to expedite regular communication and information with 
suppliers, customers, and other stakeholders [46][29][42], to keep close communication with its supplier for design consideration[47], and determine interface specifications to ensure module combinability[14]. Encompassing suppliers in quality enhancement and new product improvement helps a company to tap into their capabilities and competencies, which can moderate new product development expenses and lead times while also minimizing component mismatches [48][49]. Collaboration with suppliers for new product development and standards by firms is vital since modules require consistent specification [21]. Modular product design is based on modular components that may be assembled into several end products [50] as well as the reuse of the same modules across several end products [51], resulting in increased product volume and variety [12]. Modularity primarily influences the desirability of products by developing tenuously connected modules that may be procured from vendors [32] and merged according to consumer requirements and manufacturing processes [52]. It is critical to maintain constant, direct contact with customers and involve them in the design process to incorporate values that are important to them into the design [32]. Managers, according to Zhang, Lettice, and Zhao[39], must communicate with consumers and suppliers at the same time to incorporate MC concepts throughout the design phase. The following hypotheses are based on the previous reasoning

\section{Hypothesis $\mathrm{H} 2$}

Process Amenability is positively related to MC ability.

2.3 Competitive Environment- Competitive environment, economic uncertainty, market turbulence, firm credibility and position in the marketplace, as well as consumer loyalty, are all elements to consider in the journey to mass customization [1]. Researchers have advocated that enterprises who change from mass production to the novel paradigm of mass customization will acquire a competitive benefit [8] due to the growing awareness of mass customization. Organizations require a greater diversity of supply to meet heterogeneous and changeable consumer demand, which upsurges the ambiguity in forecasting demand for each type of product. This causes scarcities, quality concerns, and extended lead times in supplier parts, which causes manufacturing delays and limits a company's capacity to mass customise[13]. To successfully adapt to altering market wants, MC capability development necessitates extraordinary levels of process flexibility and agility inside a company[53], as well as excellent internal integration across multiple roles. The conception of mass customization has been in practice to improve an organization's ability to respond fast to dynamic changes in the global marketplace [27]. This method cannot only improve resilience, preserve operations, and support personnel during economic downturns, but also maintain a competitive advantage and accelerate business growth[41]. The following hypothesis is proposed based on the above research findings:

\section{Hypothesis H3}

Competitive Environment is positively related to MC ability.

2.4 Organizational readiness: Organizational readiness demands a thorough examination of the organization's approaches, culture, and resources [54] to determine the extent of similarity between the 
commercial opportunity offered by mass customization and the organization's capacity to profit on it [1]. To attain new and innovative forms of competitive advantage, enterprises must integrate, build, and reconfigure available resources to satisfy the expectations of a continually changing environment [17]. Before transitioning from a conventional mass production setup to a successful MC firm, enterprises must make significant changes to their historical mindsets and practices [55], since mass customization involves true change management initiatives in existing enterprises [37]. To resolve the hindrances faced by organizations while implementing mass customization, intensification of the training of designer and personnel reassignment needs to be considered for implementation of MC ability and enhancing their market competitiveness[28]. Organizational performance necessitates a group of workers with crossfunctional skills to foster creativity and innovation throughout the entire value chain to improve MC's ability to achieve organizational goals [29]. Mass customization is presented as a marketing concept that allows for the acquisition of a large number of customers while providing the opportunity to personalize the product [56]. Hence organizations require to bring a cultural change, involve their workforce in all phases of $\mathrm{MC}$ implementation, upgrade and train employees for $\mathrm{MC}$ innovative ideas, train its marketing team to understand the desire of customer and market requirements that need to be converted into various $\mathrm{MC}$ aspects of design. Such organizational readiness brings about operational agility for $\mathrm{MC}$ adaptation and implementation. Organizations having unique operational capabilities with collaborative relationships with the suppliers, flexible, innovative, and adaptive work culture has strong MC ability[29]. Tung, Baird, and Schoch [57] emphasized that top management's participation in problem resolution was crucial during crisis and conflict, therefore all across the execution phase, it was essential to simultaneously enhance production, process, and product on the strategic and tactical level, which might be a challenging assignment for top management.[40]. Effective leadership for analyzing future market potential, participation to ensure technical, economic, and personnel support, aid during obstructions, and strategic monitoring of $\mathrm{MC}$ projects and appraisal of their progress are the most important criteria for mass customization success[41]. Organizations that are flexible ensure mobility, agility, and adaptability, are more capable to reduce the response time to demand changes[58]. Companies that are self-sufficient, self-organized, linked with intelligent digitalization and forms of communication, and seem to have independent entity management teams, utilize additional supplier networks, guarantee better supply chains' capacity and access to external resources, have a protocol in place and diverse supply alternatives, and facilitate collaboration among supply chains are more ready for $\mathrm{MC}$ implementation. Thus, the following hypotheses are proposed:

\section{Hypothesis $\mathrm{H} 4$}

Organizational readiness is positively related to MC ability.

2.5 Mass customization ability- $\mathrm{MC}$ is becoming a more important strategic goal as competition grows and customers become more assertive[19]. The ability to manage change has the potential to improve operational, market, environmental, and financial performance[56]. When faced with fierce competition, many businesses want to improve their MC skills to outperform their rivals [6]. An organization's effective application of mass-customization gives a competitive edge in the industry [53] and aligns 
manufacturing with customer needs, satiating client desires[59][60], which is regarded as a key aspect for any organization's competitiveness ([21][56][61]]). Manufacturing agility can improve organizational performance by generating operational efficiency and strategic competitive advantages [60]. If each product's originality or clarity of innovation is maintained, a diverse range of options stimulates customers and opens the door to increased sales, profit margins, and revenues [43][62]]. The following hypothesis is proposed based on the previous arguments:

\section{Hypothesis H5}

Mass customization ability is positively related to competitive advantage

2.8 Research Model Fig. 1 illustrates the proposed research model, the hypothesized relationship, and the equivalent which has been previously explained in the hypotheses development section.

\section{Research Methodology}

The main goals of this study are to see how different constructs stated by Hart (1995) affect the ability of an Indian company to mass customize products, which is necessary for competitiveness.

3.1 Design of survey instrument and its reliability The four pillars of mass customization developed by Hart 1995 were adopted as the manufacturing model based on the research gap, and a preliminary collection of several factors was generated based on literature review, experience surveys, in-depth interviews, focus groups, and critical incidents [63]. The next step was to create a questionnaire based on a literature study, with each latent variable analyzed consisting of a set of items to be evaluated. There were three sections to the questionnaire. The first component of the questionnaire covers questions about the respondents' demographics, the sort of industry in which they work, and the size of their company in terms of manpower and turnover. The next section contains questions about the respondents' perceptions of their level of MC skill. The final segment contains questions about how respondents feel about various aspects of MC. The response format was a five-point Likert scale, with values ranging from 1 to 5 , with 1 indicating strong disagreement and 5 indicating strong agreement [64][65].

The questionnaire was subjected to a panel examination to ensure that it was accurate and clear [66]. This panel consisted of ten experts who were specifically briefed about the research concept and its dimensions and was finalized by engaging individually with six experts from manufacturing firms who were Managers, Vice Presidents, General Managers, Assistant General Managers, and other positions, two consultants from the field with extensive experience, and two academic experts (Ph.D. holders from prestigious universities). The expert screening process was developed in such a way that the panel of evaluators could discover items that were too identically worded [67]. The updated pool of topics was validated with a smaller group of respondents after the questionnaire was validated to ensure that all of the items were clear and understandable to the target audience [68]. The next step was scale purification, which involved using a refined and reduced scale for data collection while adhering to a sampling strategy that was adequately justified in the context of the study. 
3.2 Target organizations and target respondents: Respondent lists were obtained from reputable sources such as chambers of commerce and industry, trade organizations, and alumni associations. The most important criteria, limits, and obstacles were to identify respondents with prospective expertise to address knowledge in the questionnaire from a variety of fields covered by various domains [69]. The survey was conducted in India's manufacturing and processing industries. Companies that used or were familiar with such technology were chosen as respondents.

3.3 Collection of data: To obtain responses from potential respondents, the questionnaire was distributed both offline and online. In the case of offline mode, respondents were requested to schedule an appointment ahead of time. A soft copy of the questionnaire was then emailed to them, along with a supplemental background note on mass customization, to help them better comprehend the many aspects. A face-to-face interview was used to obtain responses from the respondents. In the instance of an online survey, participants were asked to make their beneficial inputs available. The questionnaire and background note on MC were emailed to 856 respondents from India's manufacturing businesses, representing a variety of industries. The filled-in surveys were examined to see if the respondents gave significant inputs once the online and offline responses were received.

\subsection{Respondent Characteristic}

856 respondents from India's manufacturing enterprises, covering a variety of industries, were emailed the questionnaire and background note on MC. Once the online and offline replies were collected, the filled-in surveys were analyzed to see if the respondents provided meaningful contributions. Out of the 856 surveys distributed, 286 were completed and returned. In the surveys, missing data and outliners were examined[70]. For 10 surveys, outliners were recorded, generating 276 acceptable responses. The final response rate was $32.24 \%$, which was higher than the minimum of $20 \%$ proposed by Malhotra and Grover[71] for guaranteeing the quality of the empirical research.

Sample characteristic of respondents exhibits that as per job designation, top management constituted $34.6 \%$, middle management $42.9 \%$, administrative staff $8.3 \%$, technical staff $3.9 \%$, academician $10.2 \%$. Marketing professionals accounted for $17.3 \%$ of the respondents, followed by production $16.9 \%$, procurement $15.4 \%$, logistics $11.4 \% \mathrm{t}$, R\&D $10.2 \%$, and project management $8.3 \%$. In terms of time spent in the company. $5.1 \%$ of those polled have worked for their businesses for fewer than five years. $4.3 \%$ of respondents have worked for the company for 5 to 10 years, $23.2 \%$ for 10 to 20 years and $49.6 \%$ have worked for the company for more than 20 years. Respondents had a $3.9 \%$ post-doctoral, $18.5 \%$ Ph.D., $55.1 \%$ postgraduate, $17.9 \%$ graduate, and the rest diploma holders as their educational backgrounds.

The Sample characteristic of the surveyed organization consists of consumer electronics $18.5 \%$, interiors, and decors $18.1 \%$, automotive $14.2 \%$, apparel, and footwear $9.8 \%$, food $9.1 \%$, rest were variable industries. Concerning the strength of workers, organizations with more than 1000 workers were $32.7 \%$, 1000 to 500 was $25.6 \%, 200-500$ was $18.5 \%, 100-200$ was $11 \%$, less than 100 was $12.5 \%$. Annual turnover in crores for less than 10 was $21.7 \%, 10$ to 50 was $15.4 \%, 50$ to 100 was $8.5 \%, 100$ to 500 was $17.3 \%$, more than 500 was 35.8 . 
3.5 Tests for potential bias in survey data: The responses were examined for non-response bias, which might reduce response validity (Bailey, 1978). The application of t-tests to analyze non-response bias is a common strategy, assuming that late responders (e.g., second-wave replies) can be seen as non-

responses of early responders (e.g., the first wave). For this study, 20 survey items were chosen at random for analysis, two groups of 50 surveys were picked at random from the first and last waves of surveys received, and the results of the two groups were compared using t-tests[72] with the help of SPSS program. Using t-tests, there were no statistically significant differences between the 20 survey questions. Although these findings do not rule out the possibility of non-response bias, they do show that nonresponse may not be a problem if late responders represent the views of non-respondents. As a result, scale purification and a confirmatory factor were added to the data analysis.

Because the data came from a single survey, there was a risk of common method bias [73], so Harman's single-factor test was run on the variables using SPSS and exploratory factor analysis (EFA). The findings revealed that a single component was responsible for $48.25 \%$ of the total variance, which is less than $50 \%$. The findings indicate that no one or general factor appeared, and it was considered that common technique bias was not a concern.

\section{Analysis And Results}

It is critical to ensure that the given theoretical framework is reliable and valid before testing it([74] [72]).

\subsection{Reliability and validity analysis}

Both EFA and CFA are used to test the concept's reliability and validity. To examine construct reliability, EFA is used to test the scales' unidimensionality, followed by Cronbach's alpha and composite reliability (CR)[74]. The correlated item-total-correlation (CITC) was calculated to do the reliability analysis. A CITC value of more than 0.30 is recommended. Table 1 illustrates the CITC. As indicated in Table 1, all six constructions had CITC values greater than $0.30[75]$. As a result, the scales are determined to be internally reliable, and the construct dependability of the measurement model is not impacted.

EFA with principal component analysis and varimax rotation with Kaiser normalization is carried out[39] using SPSS. The Kaiser Meyer-Olkin value of 0.941 is higher than the suggested minimum value of 0.5 [76], indicating that the sample size is sufficient. The Bartlett Test of Sphericity, which is a measure of the multivariate normality of a set of distributions and evaluated the null hypothesis in SPSS, was used to determine the strength of the link [76]. Table 2 shows how six EFA components affect the loadings of measuring scale variables. It meets the requirement of clarifying the factors and the hypothesized model based on theory because components 1,2,4, and 5 correspond to the four pillars of mass customization, namely Customer Sensitivity, Organizational Readiness, Competitive Environment, and Process Amenability, and components 3 and 6 correspond to Competitive Advantage and Mass customization Ability. From 0.689 to 0.886 , the variable loading ranges. For each construct, a Cronbach's alpha value 
was calculated, which ranged from 0.90 to 0.95 (Table 1), all of which are higher than the recommended threshold value of $0.70 .[75]$. 
Table 2

Rotated Component Matrixa

\begin{tabular}{|c|c|c|c|c|c|c|}
\hline & Comp & nent & & & & \\
\hline & 1 & 2 & 3 & 4 & 5 & 6 \\
\hline Create value for customer & .880 & .156 & .140 & .113 & .218 & .084 \\
\hline Understand uniqueness of customers' needs & .840 & .161 & .171 & .211 & .200 & .167 \\
\hline Provide ease of customer choice for decision making & .832 & .162 & .196 & .150 & .201 & .082 \\
\hline Identify opportunities for customization & .832 & .128 & .160 & .208 & .216 & .110 \\
\hline $\begin{array}{l}\text { Incorporate customer requirement during new design } \\
\text { process }\end{array}$ & .818 & .092 & .150 & .164 & .268 & .043 \\
\hline Analyze customers sacrifice for unmet needs & .794 & .185 & .167 & .220 & .164 & .087 \\
\hline Skill development of employees & .156 & .865 & .206 & .140 & .164 & .132 \\
\hline $\begin{array}{l}\text { Employees involvement in product and process } \\
\text { roadmap }\end{array}$ & .134 & .855 & .173 & .075 & .135 & .128 \\
\hline $\begin{array}{l}\text { Training to marketing team to capture and prioritize } \\
\text { requirements }\end{array}$ & .213 & .851 & .200 & .134 & .129 & .123 \\
\hline Cultural change in the organization & .100 & .848 & .185 & .178 & .109 & .110 \\
\hline Top management support and leadership building & .181 & .843 & .213 & .129 & .174 & .158 \\
\hline Increased sales volume/ Return on sales/revenue & .189 & .164 & .822 & .119 & .094 & .152 \\
\hline Market share growth/Reaching financial goals & .189 & .264 & .765 & .135 & .083 & .128 \\
\hline Reduce waste through on time production & .139 & .183 & .758 & .154 & .188 & .217 \\
\hline Acquiring new customer/Perceived customers value & .180 & .138 & .753 & .177 & .217 & .190 \\
\hline Increased product variety & .159 & .242 & .753 & .127 & .016 & .186 \\
\hline Market Turbulence & .178 & .084 & .129 & .834 & .202 & .169 \\
\hline Economic uncertainty & .211 & .065 & .135 & .792 & .195 & .166 \\
\hline Potential of competitors to react & .190 & .250 & .160 & .742 & .241 & .197 \\
\hline Customer loyalty & .301 & .214 & .178 & .679 & .203 & .218 \\
\hline Company credibility and position in marketplace & .217 & .196 & .246 & .677 & .313 & .205 \\
\hline Develop marketing competence for product promotion & .250 & .152 & .168 & .279 & .765 & .158 \\
\hline $\begin{array}{l}\text { Develop production and distribution process for timely } \\
\text { delivery }\end{array}$ & .317 & .208 & .121 & .203 & .746 & .235 \\
\hline Develop supplier for co-design & .268 & .173 & .145 & .295 & .735 & .206 \\
\hline
\end{tabular}




\begin{tabular}{|c|c|c|c|c|c|c|}
\hline & \multicolumn{6}{|c|}{ Component } \\
\hline & 1 & 2 & 3 & 4 & 5 & 6 \\
\hline Incorporate modularity in design, for part flexibility & .332 & .149 & .060 & .267 & .715 & .217 \\
\hline Develop compatible process technology & .286 & .176 & .196 & .182 & .686 & .188 \\
\hline Product can be customized on large scale & .096 & .183 & .174 & .245 & .165 & .817 \\
\hline $\begin{array}{l}\text { Product variety can be enhanced at same cost and } \\
\text { quality }\end{array}$ & .078 & .168 & .192 & .236 & .224 & .786 \\
\hline $\begin{array}{l}\text { Product can be designed based on customers' } \\
\text { requirements }\end{array}$ & .161 & .159 & .266 & .211 & .227 & .761 \\
\hline Product can be delivered on stipulated time & .158 & .157 & .398 & .154 & .249 & .684 \\
\hline $\begin{array}{l}\text { Extraction Method: Principal Component Analysis. } \\
\text { Rotation Method: Varimax with Kaiser Normalization. }\end{array}$ & & & & & & \\
\hline a. Rotation converged in 6 iterations. & & & & & & \\
\hline
\end{tabular}

Figure 2 shows a CFA model with the AMOS 23 program. Each item in the model is associated with a construct, and the covariance between those constructs is computed. The data were examined for skewness, kurtosis, and normality. There was no major violation found. According to the modification indices, no major changes were required for this model. The chi-square statistic to degrees of freedom (CMIN/DF) ratio, adjusted goodness of fit [AGFI], goodness-of-fit index GFI, root mean square residual [RMR], normed fit index NFI, Bentler comparative fit index [CFI], and root mean square error are all indicators of acceptable fit.[77] and the adequate fit suggested for models is shown in Table 2. It can be seen from Table 3 that all the measurement models have acceptable fit indices, and consequently signify the unidimensionality of the constructs.

Table 3

Model Fit Indicators for CFA

\begin{tabular}{|llllllll|}
\hline $\begin{array}{l}\text { Indicators of } \\
\text { Model Fit }\end{array}$ & CMIN/DF & AGFI & GFI & RMR & NFI & CFI & RMSEA \\
\hline Result & 1.73 & 0.83 & 0.86 & 0.032 & 0.91 & 0.96 & 0.050 \\
\hline Default Value & $\begin{array}{l}\text { Less } \\
\text { than 2 }\end{array}$ & $\begin{array}{l}\text { Greater } \\
\text { than 0.8 }\end{array}$ & $\begin{array}{l}\text { Greater } \\
\text { than 0.8 }\end{array}$ & $\begin{array}{l}\text { Less } \\
\text { than } \\
0.05\end{array}$ & $\begin{array}{l}\text { Greater } \\
\text { than 0.9 }\end{array}$ & $\begin{array}{l}\text { Greater } \\
\text { than 0.9 }\end{array}$ & $\begin{array}{l}\text { Less } \\
\text { than } \\
0.06\end{array}$ \\
\hline
\end{tabular}


After the factors are extracted using EFA and the quality of fit is confirmed using CFA, validation is done in two steps. Expert opinion is used to assess content validity, and construct validity is divided into two parts: convergent validity and discriminant validity. The values of CR (Construct Reliability) and AVE (Average Value Efficiency) determine convergent validity (Average Value). The CR and AVE values should both be more than 0.7 and 0.5 , with CR always being bigger than AVE[78]. Discriminant validity is determined using MSV values (Mean Shared Variance)[77]. The AVE value should always exceed the MSV value. Table 4 backs up the findings, and both convergent and discriminant validities exist.

Table 4: Assessment of Discriminant Validity and Convergent Validity

\begin{tabular}{|c|c|c|c|c|c|c|c|c|c|c|}
\hline & CR & AVE & MSV & Asv & $\begin{array}{l}\text { Customer } \\
\text { Sensitivity }\end{array}$ & \begin{tabular}{|l|} 
Process \\
Amenability
\end{tabular} & $\begin{array}{l}\text { Competitive } \\
\text { Environment }\end{array}$ & $\begin{array}{c}\text { Organizational } \\
\text { Readiness }\end{array}$ & $\begin{array}{l}\text { Mass } \\
\text { Customiration }\end{array}$ & $\begin{array}{l}\text { Compititive } \\
\text { Advantage }\end{array}$ \\
\hline Customer Sensitwity & 0.96 & 0.80 & 0.45 & 0.28 & 0.89 & & & & & \\
\hline Process Amenability & 0.92 & 0.71 & 0.52 & 0.37 & 0.67 & 0.84 & & & & \\
\hline Competitive Environment & 0.91 & 0.66 & 0.52 & 0.37 & 0.59 & 0.72 & 0.81 & & & \\
\hline Organizational Readiness & 0.95 & 0.81 & 0.27 & 0.25 & 0.45 & 0.50 & 0.52 & 0.90 & & \\
\hline Mass_Customization & 0.90 & 0.71 & 0.42 & 0.33 & 0.44 & 0.65 & 0.65 & 0.49 & 0.84 & \\
\hline Compititive_Advantage & 0.90 & 0.66 & 0.41 & 0.30 & 0.45 & 0.5 & 0.56 & 0.55 & 0.64 & 0.81 \\
\hline
\end{tabular}

\subsection{Means, standard deviations, and correlations}

To acquire a thorough grasp of the data, descriptive statistical analysis was used. As a result, descriptive statistics and bivariate correlation data derived from the Pearson coefficient correlation approaches have been assessed (Table 5). Table 5 reveals that the correlation coefficients for the constructs are greater than 0.40 at the 0.01 level (2-tailed), showing that they are positive and statistically significantly correlated[79]. However, because no relationship is greater than 0.70 , multi-collinearity is unnecessary [79].

Table 5: Descriptive analysis and correlations

\begin{tabular}{|l|r|r|r|l|l|l|l|l|}
\hline & Mean & SD & $\begin{array}{l}\text { Customer } \\
\text { Sensitivity }\end{array}$ & $\begin{array}{l}\text { Process } \\
\text { Amenability }\end{array}$ & $\begin{array}{l}\text { Competitive } \\
\text { Environment }\end{array}$ & $\begin{array}{l}\text { Organizational } \\
\text { Readiness }\end{array}$ & $\begin{array}{l}\text { Mass } \\
\text { Customization }\end{array}$ & $\begin{array}{l}\text { Compititive } \\
\text { Advantage }\end{array}$ \\
\hline Customer Sensitivity & 3.74 & 0.96 & 1 & & & & & \\
\hline Process Amenability & 3.79 & 0.88 & 0.67 & 1 & & & & \\
\hline Competitive Environment & 3.80 & 0.79 & 0.59 & 0.70 & 1 & & & \\
\hline Organizational Readiness & 3.87 & 0.89 & 0.45 & 0.50 & 0.52 & 1 & & \\
\hline Mass_Customization & 3.95 & 0.75 & 0.44 & 0.65 & 0.65 & 0.49 & 1 & \\
\hline Compititive_Advantage & 3.88 & 0.72 & 0.45 & 0.50 & 0.56 & 0.55 & 0.64 & 1 \\
\hline
\end{tabular}

\subsection{Hypothesis Testing}


Using AMOS 23, SEM analysis was used to analyze the associations between each pair of postulated components, as shown in Table 6. Figure 3 shows a path diagram created with the AMOS software., which portrays the results of analysis derived from the SEM. Model fit indices values shows good fit $(\mathrm{CMIN} / \mathrm{DF}=1.83 ; \mathrm{GFI}=0.85 ; \mathrm{AGFI}=0.83, \mathrm{NFI}=0.91, \mathrm{CFI}=0.95, \mathrm{RMSEA}=0.05)$. All these values are satisfactory for the recommended range values.

Table 6

Result of Hypothesis testing

\begin{tabular}{|llllll|}
\hline & Hypothesis & B & C.R( $\boldsymbol{\beta})$ & $\begin{array}{l}\text { p- } \\
\text { value }\end{array}$ & Supported \\
\hline H1 & Customer sensitivity is positively related to MC ability & -0.05 & -0.096 & 0.33 & $\begin{array}{l}\text { Not } \\
\text { Supported }\end{array}$ \\
\hline H2 & Process Amenability is positively related to MC ability & 0.28 & 4.07 & 0.00 & Supported \\
\hline H3 & $\begin{array}{l}\text { Competitive Environment is positively related to MC } \\
\text { ability }\end{array}$ & 0.34 & 4.32 & 0.00 & Supported \\
\hline H4 & $\begin{array}{l}\text { Organizational readiness is positively related to MC } \\
\text { ability. }\end{array}$ & 0.14 & 3.12 & 0.002 & Supported \\
\hline H5 & $\begin{array}{l}\text { Mass customization ability is positively related to } \\
\text { competitive advantage }\end{array}$ & 0.69 & 10.23 & 0.00 & Supported \\
\hline
\end{tabular}

In terms of the impact of customer sensitivity on MC ability, the SEM results do not support $\mathrm{H} 1$, the path coefficient is $\beta=-.05, t=-.096$, thus disagreeing with the suggestions of Hart (1995) that the customers' needs and wants, and his sacrifice for unmet needs requires to be considered by any organization before shifting from mass production to mass customization. The result is surprising, but it may be because the analysis was carried out in India where mass customization is at its nascent stage, and respondent's ability to analyze the gap between products provided and products desired by the customer gives rise to mass customization ability was crucial. As hypothesized, a significant relationship between Process Amenability and mass customization ability is observed $(\beta=0.28, t=4.07$, significant at $p<0.00)$, thus supporting H2. This concurs with the research by Hart (1995) that organizational enablers, marketing competence, supportive production and distribution team, and design aspects can enhance the mass customization ability of a firm. Hypothesis $\mathrm{H} 3$ is supported $(\beta=0.34, t=4.32$, significant at $p<0.00)$, acceding Hart's research theory that a competitive environment promotes mass customization. Hypothesis $\mathrm{H} 4$ showing Organizational Readiness leads to mass customization ability is supported $(\beta=$ $0.14, t=3.12$, significant at $p<0.002)$, harmonizing with research by Hart (1995) that organizations need to identify the fit between business opportunity and organizations ability to capitalize on this opportunity before venturing into mass customization. Finally, $\mathrm{H} 5$ is supported $(\beta=0.69, \mathrm{t}=10.23$, significant at $p<$ 0.000), emphasizing that MC-capable manufacturing plants may dynamically modify their resource/skill mix to adapt to individual client demands, gaining a competitive advantage [13]. 


\section{Results And Discussion}

To meet customer demand in a certain period, a manufacturing company must choose the best acceptable product configuration from a wide range of options to achieve effective $\mathrm{MC}$, which in turn relies on the firm's capacity to effectively grasp client wants and obtain the necessary mix and quantity of components for timely assembly of the needed product configuration. The goal of this study is to categorize, consolidate, and validate important components that influence the ability of Indian manufacturing companies to integrate mass customization. Hart's (1995)'s four pillars of mass customization were used to identify constructs, which are then followed by a systematic literature review to identify measurement items. The study used this information to describe the links between mass customization and competitive advantage, as well as give empirical evidence for the proposed research technique.

The disruption caused by COVID-19 on manufacturing has a considerable influence on operational, social, and financial sectors, as well as posing challenges to organizations attempting to accelerate the change of global value distribution models, effectively halting many Indian industries. The manufacturing sector in India is now at a crossroads with unprecedented consequences for manufacturers and supply chains[41]. A new method is required to limit the impact of COVID-19 and rethink risk management and contingency plans. This empirical model of mass customization can provide manufacturers with a solution to the pressing issues that must be addressed to make the business as stable as possible. This strategy will not only improve resilience, protect operations, and support people during the crisis, but it will also help businesses maintain a competitive advantage and accelerate growth after the economy recovers.

\section{Managerial Implications}

The practical goal of the research is to provide strategic instructions to top-level manufacturing executives to encourage mass customization for business excellence. According to the findings of the study, the competitive environment has a significant impact on mass customization, which is consistent with Hart's (1995) research findings that organizations should shift from mass production to mass customization only when market turbulence occurs, resulting in homogeneous versus heterogeneous customer demand. However, the first-mover advantage can only be guaranteed if there is customer loyalty and a good reputation in the market. Because of the turbulence that has disrupted the mass market, mass customization should be regarded as an organizational approach. Firms should view market volatility as an opportunity rather than a hindrance or a threat to which they should escape [1].

Once the organization had identified its potential to venture into mass customization, it needs to strengthen the other three pillars simultaneously. Customer sensitivity that identifies the uniqueness of customer needs and sacrifices for unmet needs should be deciding factor for the type of masscustomized product, which should cogitate the voice of the customer during the new design process. The other pillar Process Amenability needs to empower production, process, distribution, vendor for co- 
development, and marketing team to be 'market ready' for mass customization. The fourth pillar, requires firstly, top management involvement (highest factor loading) and employee empowerment to ensure a cultural change, followed by skill development of employees for the successful attainment of mass customization goals.

The above guidelines provide a framework and guidelines for managers willing to implement mass customization.

\section{Limitations Of The Study And Future Research Direction}

There were several limitations, as with any empirical study, that necessitated additional research. The study is both national and industrial. Future applications should test this model in another country to validate it across other markets. Second, the study focuses on the manufacturing sectors. In the future, a comparative cross-industry study could be conducted to evaluate the model proposed in this study in other industries. The model can likewise be put to the test in the service sector.

Future research could include elements not included in this study, such as financial concerns. This framework is best suited for companies with a solid technical foundation. A comparable framework for MSMEs and start-ups may be investigated for the use of mass customization in a variety of businesses. Furthermore, the aforementioned concept was put to the test for mass customization to gain a competitive advantage. It is possible to test the same model to see if it is profitable for a business.

\section{Declarations}

1. Funding (No funds, grants, or other support was received.)

2. Conflicts of interest/Competing interests: The authors have no conflicts of interest to declare that are relevant to the content of this article.

3. Availability of data and material (Data will be made available as desired by journal)

4. Code availability (Not applicable)

5. Ethics approval (The authors have abided by the ethics policies of the journal)

6. Consent to participate (Author and co-authors consent to participate)

7. Consent for publication (Author and co-authors consent for publication )

8. Authors' contributions All authors certify that they have no affiliations with or involvement in any organization or entity with any financial interest or non-financial interest in the subject matter or materials discussed in this manuscript.

\section{References}

1. Hart CWL (1995) Mass customization: Conceptual underpinnings, opportunities and limits. Int J Serv Ind Manag 6:36-45. https://doi.org/10.1108/09564239510084932 
2. Alon I, Pilla V, Bretas G (2021) COVID-19 and International Business

3. Deshmukh SG, Haleem A (2020) Framework for Manufacturing in Post-COVID-19 World Order: An Indian Perspective. Int J Glob Bus Compet 15:49-60. https://doi.org/10.1007/s42943-020-00009-1

4. Vekic A, Borocki J, Fajsi A (2020) MASS CUSTOMIZATION STRATEGIES IN PANDEMIC CONDITIONS. 234-240

5. Brown S, Bessant J (2003) The manufacturing strategy-capabilities links in mass customisation and agile manufacturing - An exploratory study. Int J Oper Prod Manag 23:707-730. https://doi.org/10.1108/01443570310481522

6. Liu G, Shah R, Babakus E (2012) liu,shah,babakus(2012)When to Mass Customize The Impact of.pdf. 43:851-887

7. Andújar-Montoya MD, Gilart-Iglesias V, Montoyo A, Marcos-Jorquera D (2015) A construction management framework for mass customisation in traditional construction. Sustain 7:5182-5210. https://doi.org/10.3390/su7055182

8. Kotha $S$ (1996) From mass production to mass customization: The case of the national industrial bicycle company of Japan. Eur Manag J 14:442-450. https://doi.org/10.1016/02632373(96)00037-0

9. McCarthy IP (2004) Special issue editorial: The what, why and how of mass customization. Prod Plan Control 15:347-351. https://doi.org/10.1080/0953728042000238854

10. Anant D (2017) Article information: Relationships between Advanced Manufacturing Technologies, Absorptive Performance : An Empirical Investigation. "Relationships between Adv Manuf Technol Absorptive Capacit Mass Cust Time to Mark Financ Mark Perform An Empir Investig Asia-Pacific J Bus Adm https//doi.org/101108

11. Kristal MM, Huang X, Schroeder RG (2010) The effect of quality management on mass customization capability. Int J Oper Prod Manag. https://doi.org/10.1108/01443571011075047

12. Ahmad S, Schroeder RG, Mallick DN (2010) The relationship among modularity, functional coordination, and mass customization: Implications for competitiveness. Eur J Innov Manag. https://doi.org/10.1108/14601061011013221

13. Liu GJ, Shah R, Schroeder RG (2012) The relationships among functional integration, mass customisation, and firm performance. Int J Prod Res 50:677-690. https://doi.org/10.1080/00207543.2010.537390

14. Heim DXPG (Jason) LGR (2011) Impacts of information technology on mass customization capability of manufacturing plants. Int J Oper Prod Manag 31 Iss 10 1022-1047 34:1-5

15. Liu G, Shah R, Schroeder RG (2006) Linking work design to mass customization: A sociotechnical systems perspective. Decis Sci. https://doi.org/10.1111/j.1540-5414.2006.00137.x

16. Wong $H$, Eyers $D$ (2011) An analytical framework for evaluating the value of enhanced customisation: An integrated operations-marketing perspective. Int J Prod Res 49:5779-5800. https://doi.org/10.1080/00207543.2010.519738 
17. Lai F, Zhang M, Lee DMS, Zhao X (2012) The impact of supply chain integration on mass customization capability: An extended resource-based view. IEEE Trans Eng Manag 59:443-456. https://doi.org/10.1109/TEM.2012.2189009

18. Aihua E, Li X, Lu, JiajuFang N (2016) Effects of organizational learning on process technology and operations performance in mass customizers. Int J Prod Econ 174:68-75. https://doi.org/10.1016/j.ijpe.2016.01.019

19. Huang X, Kristal MM, Schroeder RG (2010) The impact of organizational structure on mass customization capability: A contingency view. Prod Oper Manag 19:515-530. https://doi.org/10.1111/j.1937-5956.2009.01117.x

20. Dash P (2019) Mass customization. Int J Psychosoc Rehabil. https://doi.org/10.37200/IJPR/V2316/PR190782

21. Zhang $M$, Guo H, Huo B et al (2019) Linking supply chain quality integration with mass customization and product modularity. Int J Prod Econ. https://doi.org/10.1016/j.ijpe.2017.01.011

22. Piller FT, Moeslein K, Stotko CM (2004) Does mass customization pay? An economic approach to evaluate customer integration. Prod Plan Control 15:435-444. https://doi.org/10.1080/0953728042000238773

23. Wong $\mathrm{H}$, Lesmono $\mathrm{D}$ (2013) On the evaluation of product customization strategies in a vertically differentiated market. Int J Prod Econ 144:105-117. https://doi.org/10.1016/j.ijpe.2013.01.023

24. Wang Y, Ma HS, Yang JH, Wang KS (2017) Industry 4.0: a way from mass customization to mass personalization production. Adv Manuf. https://doi.org/10.1007/s40436-017-0204-7

25. Zhong RY, Dai QY, Qu T et al (2013) RFID-enabled real-time manufacturing execution system for mass-customization production. Robot Comput Integr Manuf. https://doi.org/10.1016/j.rcim.2012.08.001

26. Shukla M, Todorov I, Kapletia D (2018) Application of additive manufacturing for mass customisation: understanding the interaction of critical barriers. Prod Plan Control 29:814-825. https://doi.org/10.1080/09537287.2018.1474395

27. Yao S, Han X, Yang Y et al (2007) Computer-aided manufacturing planning for mass customization: Part 1, framework. Int J Adv Manuf Technol 32:194-204. https://doi.org/10.1007/s00170-005-0327Z

28. An W, Yang W, Guo W, Zhu D (2014) Research on enterprise customization diagnosis for mass customization. Int J Adv Manuf Technol 76:669-674. https://doi.org/10.1007/s00170-014-6315-4

29. Ullah I, Narain R (2018) Analysis of interactions among the enablers of mass customization: An interpretive structural modelling approach. J Model Manag 13:626-645. https://doi.org/10.1108/JM2-04-2017-0048

30. Purohit JK, Mittal ML, Mittal S, Sharma MK (2016) Interpretive structural modeling-based framework for mass customisation enablers: an Indian footwear case. Prod Plan Control 27:774-786. https://doi.org/10.1080/09537287.2016.1166275 
31. Liao K, Deng X, Marsillac E (2013) Factors that influence Chinese automotive suppliers' mass customization capabilities. Int J Prod Econ 146:25-36. https://doi.org/10.1016/j.ijpe.2013.01.014

32. Pedzik M, Bednarz J, Kwidzinski Z et al (2020) The idea of mass customization in the door industry using the example of the company porta KMI Poland. Sustain 12:. https://doi.org/10.3390/su12093788

33. Li DC, Chang FM, Chang SC (2010) The relationship between affecting factors and masscustomisation level: The case of a pigment company in Taiwan. Int J Prod Res 48:5385-5395. https://doi.org/10.1080/00207540903130884

34. (Jason) Liu G, Zhang W, Guo C (2018) Impacts of supply chain planning and integration on mass customization. J Manuf Technol Manag 29:608-628. https://doi.org/10.1108/JMTM-08-2017-0162

35. Tookanlou PB, Wong H (2020) Determining the optimal customization levels, lead times, and inventory positioning in vertical product differentiation. Int J Prod Econ 221: https://doi.org/10.1016/j.ijpe.2019.08.014

36. Trentin A, Forza C, Perin E (2012) Organisation design strategies for mass customisation: An information-processing-view perspective. Int J Prod Res 50:3860-3877. https://doi.org/10.1080/00207543.2011.597790

37. Kotha S, Yoo J, Park M et al (2004) The manufacturing strategy-capabilities links in mass customisation and agile manufacturing - An exploratory study. Int J Prod Econ 15:707-730. https://doi.org/10.1108/09564239510084932

38. Piller FT (2004) Piller - Mass Customization Reflections on the State of the Concept - 2005.pdf. Flex Serv Manuf J 313-334

39. Zhang M, Lettice F, Zhao X (2015) The impact of social capital on mass customisation and product innovation capabilities. Int J Prod Res 53:5251-5264. https://doi.org/10.1080/00207543.2015.1015753

40. Mourtzis $D$ (2016) Challenges and future perspectives for the life cycle of manufacturing networks in the mass customisation era. Logist Res 9:1-20. https://doi.org/10.1007/s12159-015-0129-0

41. Jain P, Garg S, Kansal G (2021) A TISM approach for the analysis of enablers in implementing mass customization in Indian manufacturing units A TISM approach for the analysis of enablers in implementing mass customization in Indian manufacturing units. Prod Plan Control 0:1-16. https://doi.org/10.1080/09537287.2021.1900616

42. Tang M, Qi Y, Zhang M (2017) Impact of Product Modularity on Mass Customization Capability: An Exploratory Study of Contextual Factors. Int J Inf Technol Decis Mak 16:939-959. https://doi.org/10.1142/S0219622017410012

43. Gunasekaran A, Yusuf YY, Adeleye EO, Papadopoulos T (2018) Agile manufacturing practices: the role of big data and business analytics with multiple case studies. Int J Prod Res 56:385-397. https://doi.org/10.1080/00207543.2017.1395488

44. Dean PR, Tu YL, Xue D (2009) An information system for one-of-a-kind production. Int J Prod Res 47:1071-1087. https://doi.org/10.1080/00207540701543593 
45. Zipkin $P$ (2001) The limits of mass customization. MIT Sloan management review,. 42(3), p.8

46. Forza C, Salvador F (2008) Application support to product variety management. Int J Prod Res. https://doi.org/10.1080/00207540600818278

47. Kortmann S, Gelhard C, Zimmermann C, Piller FT (2014) Linking strategic flexibility and operational efficiency: The mediating role of ambidextrous operational capabilities. J Oper Manag 32:475-490. https://doi.org/10.1016/j.jom.2014.09.007

48. Romano P, Vinelli A (2001) Quality management in a supply chain perspective. Int J Oper Prod Manag 21:446-460. https://doi.org/10.1108/01443570110381363

49. Yeung JHY, Selen W, Zhang M, Huo B (2009) The effects of trust and coercive power on supplier integration. Int J Prod Econ 120:66-78. https://doi.org/10.1016/j.ijpe.2008.07.014

50. Ulrich K (1995) The role of product architecture in the manufacturing firm. Res Policy 24:419-440. https://doi.org/10.1016/0048-7333(94)00775-3

51. Fisher M, Ramdas K, Ulrich K (1999) Component sharing in the management of product variety: A study of automotive braking systems. Manage Sci 45:297-315.

https://doi.org/10.1287/mnsc.45.3.297

52. Salvador F, Rungtusanatham M, Forza C (2004) Supply-chain configurations for mass customization. Prod Plan Control 15:381-397. https://doi.org/10.1080/0953728042000238818

53. Kotha S (1995) Mass customization: Implementing the emerging paradigm for competitive advantage. Strateg Manag J 16:21-42. https://doi.org/10.1002/smj.4250160916

54. Helms MM, Ahmadi M, Jih WJK, Ettkin LP (2008) Technologies in support of mass customization strategy: Exploring the linkages between e-commerce and knowledge management. Comput Ind 59:351-363. https://doi.org/10.1016/j.compind.2007.09.003

55. McIntosh RI, Matthews J, Mullineux G, Medland AJ (2010) Late customisation: Issues of mass customisation in the food industry. Int J Prod Res 48:1557-1574.

https://doi.org/10.1080/00207540802577938

56. Sheng H, Feng T, Chen $L$ et al (2020) Motives and performance outcomes of mass customization capability: evidence from Chinese manufacturers. J Manuf Technol Manag.

https://doi.org/10.1108/JMTM-02-2020-0065

57. Tung A, Baird K, Schoch HP (2011) Factors influencing the effectiveness of performance measurement systems. Int J Oper Prod Manag 31:1287-1310.

https://doi.org/10.1108/01443571111187457

58. Godinic DaObrenovicB, Du J, Tsoy D et al (2020) Sustaining enterprise operations and productivity during the COVID-19 pandemic: "Enterprise effectiveness and sustainability model. Sustain 12:1-27. https://doi.org/10.3390/su12155981

59. Dean PR, Xue D, Tu YL (2009) Prediction of manufacturing resource requirements from customer demands in mass-customisation production. Int J Prod Res 47:1245-1268.

https://doi.org/10.1080/00207540701557197

Page 22/26 
60. Wang Z, Zhang M, Sun H, Zhu G (2016) Effects of standardization and innovation on mass customization: An empirical investigation. Technovation 48-49:79-86. https://doi.org/10.1016/j.technovation.2016.01.003

61. Liu X, Zhao X, Zhao H (2018) Absorptive capacity and business performance: The mediating effects of innovation and mass customization. Ind Manag Data Syst 118:1787-1803. https://doi.org/10.1108/IMDS-09-2017-0416

62. Ellena T, Mustafa H, Subic A, Pang TY (2018) A design framework for the mass customisation of custom-fit bicycle helmet models. Int J Ind Ergon 64:122-133. https://doi.org/10.1016/j.ergon.2018.01.005

63. Malhotra NK, Mukhopadhyay S, Liu X, Dash S (2012) One, few or many? an integrated framework for identifying the items in measurement scales. Int J Mark Res 54:835-862. https://doi.org/10.2501/IJMR-54-6-835-862

64. Das D (2018) Sustainable supply chain management in Indian organisations: an empirical investigation. Int J Prod Res 56:5776-5794. https://doi.org/10.1080/00207543.2017.1421326

65. De Lange P, Jackling B, Suwardy $T$ (2015) Continuing Professional Development in the Accounting Profession: Practices and Perceptions from the Asia Pacific Region. Account Educ 24:41-56. https://doi.org/10.1080/09639284.2014.1002800

66. Mendes L, MacHado J (2015) Employees skills, manufacturing flexibility and performance: A structural equation modelling applied to the automotive industry. Int J Prod Res 53:4087-4101. https://doi.org/10.1080/00207543.2014.993772

67. Maklan S, Klaus P (2011) Customer experience: Are we measuring the right things? Int J Mark Res 53:5. https://doi.org/10.2501/ijmr-53-6-771-792

68. Reynolds N, Diamantopoulos A (1998) The effect of pretest method on error detection rates. Eur J Mark 32:480-498. https://doi.org/10.1108/03090569810216091

69. Valase K, Raut DN (2019) Mediation analysis of multiple constructs in the relationship between manufacturing and technology and environmental constructs in structural equation model for sustainable manufacturing. Int J Adv Manuf Technol 101:1887-1901. https://doi.org/10.1007/s00170-018-2979-5

70. Schreiber JB, Stage FK, King J et al (2006) Reporting structural equation modeling and confirmatory factor analysis results: A review. J Educ Res 99:323-338. https://doi.org/10.3200/JOER.99.6.323338

71. Malhotra MK, Grover V (1998) An assessment of survey research in POM: From constructs to theory. J Oper Manag 16:407-425. https://doi.org/10.1016/s0272-6963(98)00021-7

72. Krause DR, Pagell M, Curkovic S (2001) Toward a measure of competitive priorities for purchasing. J Oper Manag 19:497-512. https://doi.org/10.1016/S0272-6963(01)00047-X

73. Podsakoff PM, MacKenzie SB, Lee JY, Podsakoff N (2003) Common method biases in behavioral research: a critical review of the literature and recommended remedies. J Appl Psychol 88:879 
74. Fornell C, Larcker DF (1981) Fornell, C. and Larcker DF (1981), "Evaluating structural equation models with unobservable variables and.pdf. J Mark Res XVIII:39-50

75. Nunnally JC, Bernstein I (1994) Psychometric Theory. New York McGraw-Hill

76. Ul Hadia N, Abdullah N, Sentosa I (2016) An Easy Approach to Exploratory Factor Analysis: Marketing Perspective. J Educ Soc Res 6:215-223. https://doi.org/10.5901/jesr.2016.v6n1p215

77. Chen IJ, Paulraj A (2004) Towards a theory of supply chain management: The constructs and measurements. J Oper Manag 22:119-150. https://doi.org/10.1016/j.jom.2003.12.007

78. Khurana S, Haleem A, Mannan B (2019) Determinants for integration of sustainability with innovation for Indian manufacturing enterprises: Empirical evidence in MSMEs. J Clean Prod 229:374-386. https://doi.org/10.1016/j.jclepro.2019.04.022

79. Shashi, Centobelli P, Cerchione R, Singh R (2019) The impact of leanness and innovativeness on environmental and financial performance: Insights from Indian SMEs. Int J Prod Econ 212:111-124. https://doi.org/10.1016/j.ijpe.2019.02.011

\section{Figures}

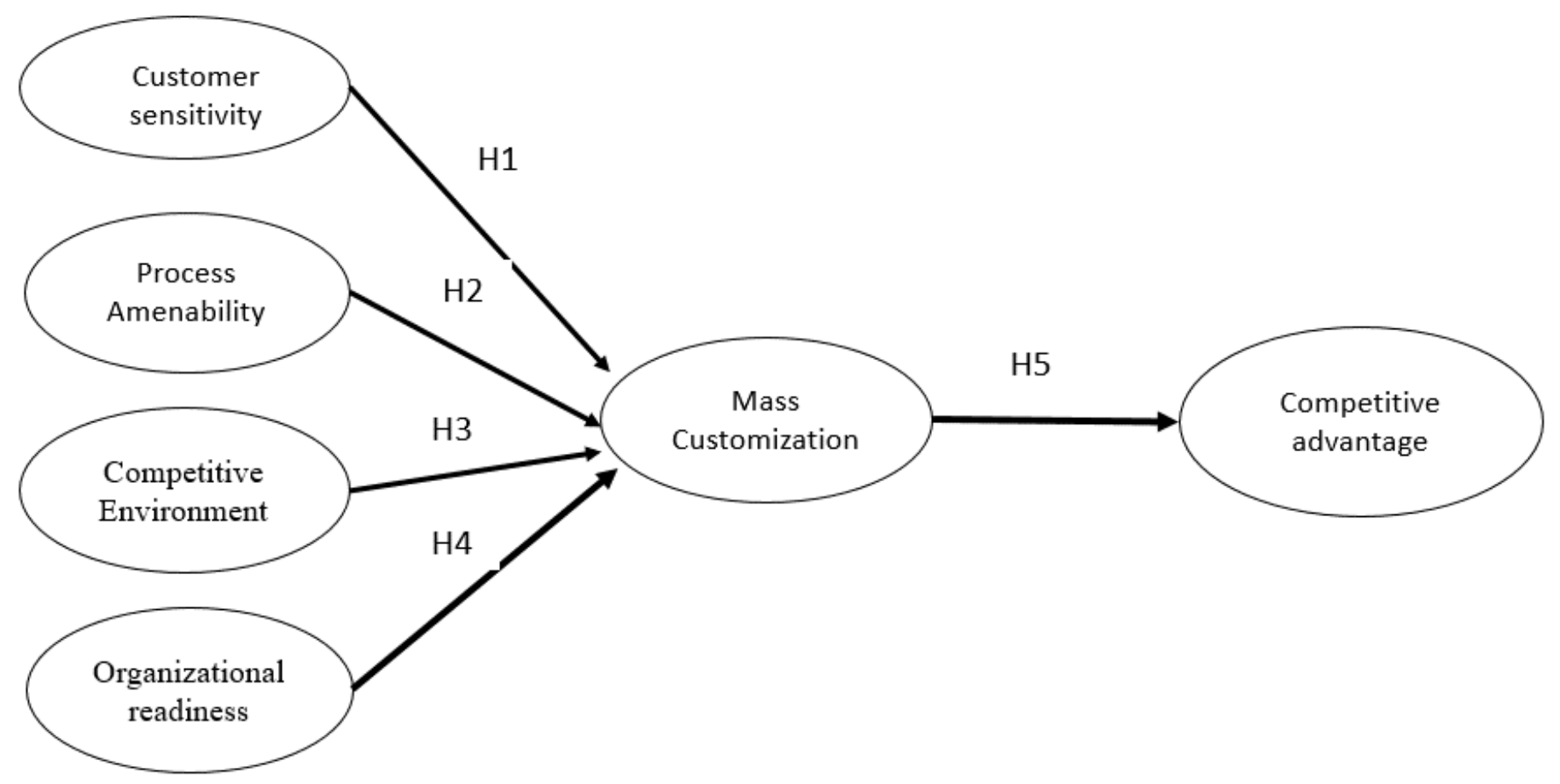

\section{Figure 1}

Research Framework 


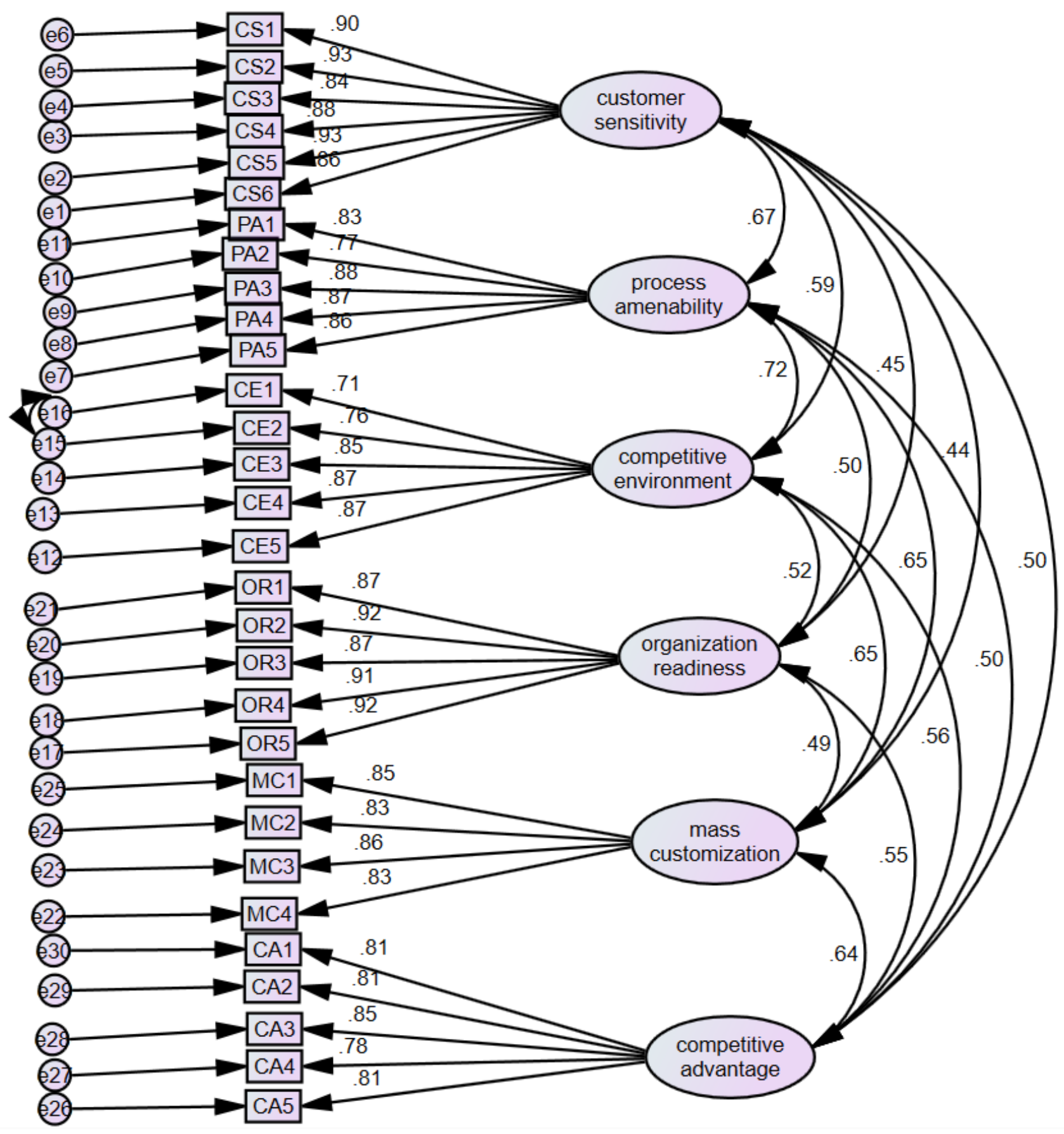

Figure 2

Path diagram showing the regression weights and the correlation between the Constructs 


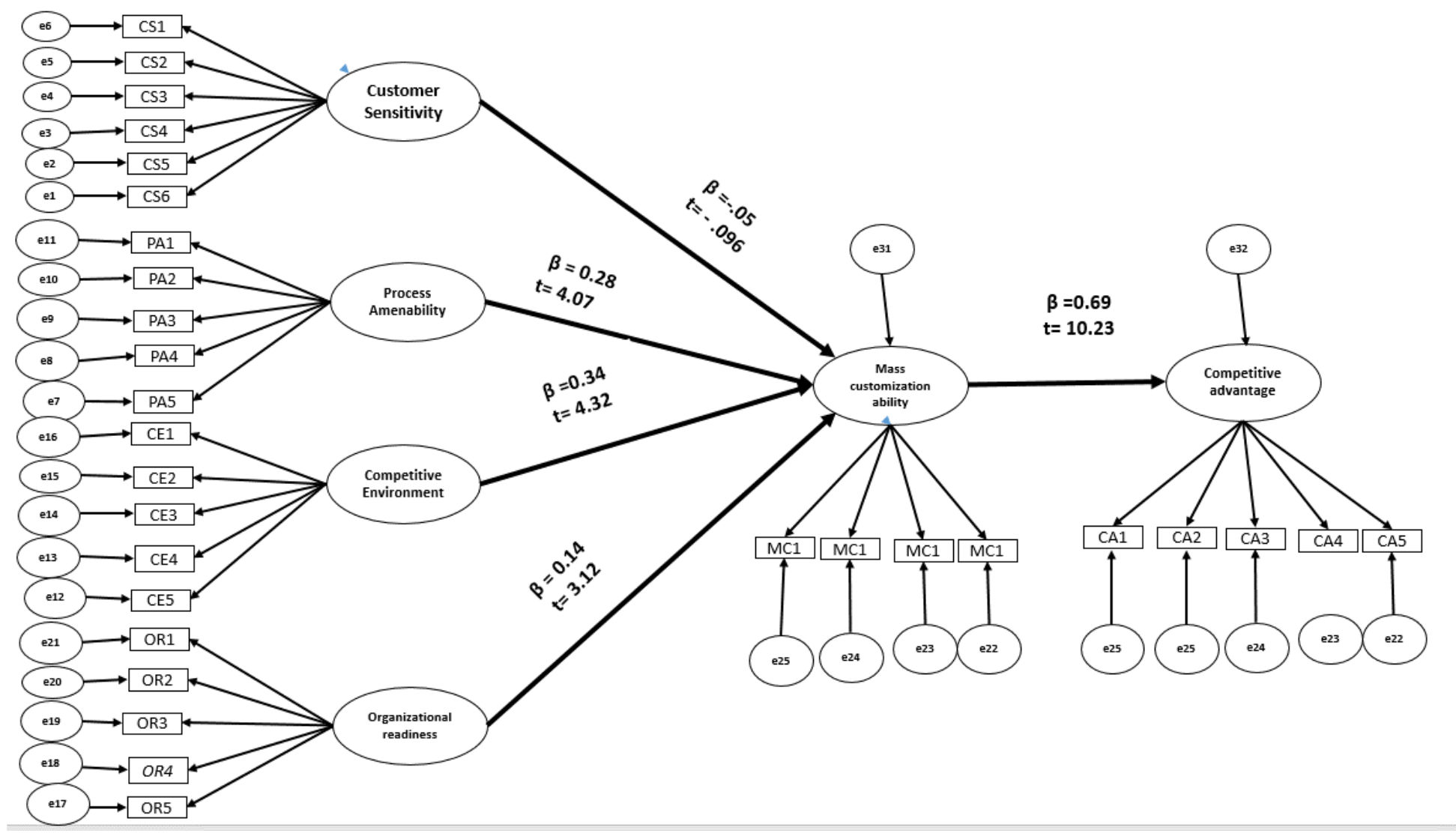

Figure 3

Path Diagram of Structural Equation Model

\section{Supplementary Files}

This is a list of supplementary files associated with this preprint. Click to download.

- Authorsbiography.docx 